\title{
Peningkatan Kompetensi Orang Tua dalam Mendampingi Anak Mengakses Gadget
}

\author{
${ }^{1}$ Wisnu Sri Hertinjung, ${ }^{2}$ Adinda Ratna Dwi Septianingrum, ${ }^{3}$ Yuliana Pratiwi Sumarno Putri \\ Universitas Muhammadiyah Surakarta \\ Email: ${ }^{1}$ wh171@ums.ac.id, ${ }^{2}$ adindaaratnaa22@gmail.com, ${ }^{3}$ f100160105@student.ums.ac.id
}

\section{Article Info}

Submitted: 26 June 2020

Revised: 19 August 2020

Accepted: 7 December 2020

Published: 21 April 2021

Keywords: preschool children, gadgets, psychoeducation
Kata kunci: Anak prasekolah, gadget, penyuluhan

\begin{abstract}
Gadgets is be a device that couldn't be separated of life, even on child preschool. Preschool children, is the Alpha generation that has been born with technology. As device other technology, gadgets have benefit also have a negative impact. The use of gadgets that are not monitored, can bring have an adverse impact on child development. The role of parents in accompanying child while using gadget to be a very important. Unfortunately, still have constraints parents as the understanding on children development preschool, the impact of positive and negative gadgets, and the limited skill of parents to apply the rules of consistent related to the use of gadgets. This problem needs to be overcome that parents can serve optimal and gadgets used capable of supported the development of knowledge children. Therefore, counseling about assistance gadgets for the preschools children to be done. The counseling participants consisted of parents of Baithul Athfal Aisyiah Trangsan 01, teachers, and administrators of Aisyiyah Ranting Trangsan. The method used in this counseling is lectures and group discussion. The effectiveness of psychoeducation is revealed from questionnaires filled out by the participants, before and after counseling. Based on the analysis of data using wilcoxon signed rank test, $z=-3,134$ with $p=0,002$ ( $p \& 0,05)$, It is means there were very significant differences between parents knowledge before and after counseling. Qualitatively, the majority of mother feel worried when he played gadgets; mother hope the child can reduce his habit of playing gadgets and use them to the extent of learning facilities; what the majority of mothers do is provide time limits, types of viewing, and try to assist children when playing gadgets.
\end{abstract}

\begin{abstract}
Abstrak
Gadget menjadi perangkat yang tidak bisa dipisahkan dari kehidupan sehari-hari, sekalipun pada anak prasekolah. Anak prasekolah (Taman Kanak-kanak), merupakan generasi Alfa yang sejak lahir telah berinteraksi dengan teknologi. Namun sebagaimana perangkat teknologi yang lain, gadget selain memiliki manfaat juga memiliki
\end{abstract}


dampak negatif. Penggunaan gadget yang tidak dipantau, dapat membawa dampak yang merugikan bagi tumbuh kembang anak. Peran orang tua dalam mendampingi anak saat menggunakan gadget menjadi hal yang penting. Hanya saja, masih terdapat kendala, seperti kurangnya pemahaman orang tua mengenai tumbuh kembang anak prasekolah, dampak positif dan negatif gadget, serta keterbatasan keterampilan orang tua untuk menerapkan aturan yang konsisten terkait penggunaan gadget. Kendala-kendala ini perlu diatasi agar orang tua dapat berperan optimal dan gadget yang digunakan dapat mendukung perkembangan pengetahuan anak. Dengan demikian, penyuluhan tentang pendampingan penggunaan gadget untuk anak prasekolah perlu dilakukan. Peserta penyuluhan terdiri dari orang tua siswa Baithul Athfal Aisyiah Trangsan 01, guru, dan pengurus Aisyiyah Ranting Trangsan berjumlah 36 orang. Metode yang digunakan adalah ceramah dan diskusi kelompok. Efektivitas penyuluhan ini diketahui dari kuesioner yang diisi sebelum dan sesudah penyuluhan. Berdasarkan hasil analisis data menggunakan Wilcoxon Signed Rank Test, diperoleh $\mathrm{Z}=-3,134$ dengan $\mathrm{p}=0,002(\mathrm{p}<0,05)$, artinya terdapat perbedaan yang sangat signifikan pengetahuan orang tua sebelum dan sesudah penyuluhan. Secara kualitatif, mayoritas ibu merasa khawatir ketika anaknya bermain gadget; ibu berharap anak dapat mengurangi kebiasaannya bermain gadget dan menggunakannya sebatas untuk fasilitas belajar. Hal yang mayoritas akan ibu lakukan adalah memberikan batasan waktu, jenis tontonan, dan berusaha dapat mendampingi anak saat bermain gadget

\section{PENDAHULUAN}

Baitul Athfal (BA) Aisyiyah Trangsan 01 bertempat di Mandungan RT 02 RW 10 Trosemi, Gatak, Sukoharjo. Lokasi BA Aisyiyah Trangsan 01 ini sangat strategis karena berada di pinggir jalan raya Kecamatan Gatak. Kecamatan Gatak adalah salah satu Kecamatan di Kabupaten Sukoharjo dengan luas daerah $1.947 \mathrm{Ha}$, jarak kecamatan ke ibu kota Sukoharjo $\pm 24 \mathrm{~km}$ sebelah selatan berbatasan dengan Kecamatan Wonosari, Kabupaten Klaten, sebelah Utara berbatasan dengan Kecamatan Kartasura, sebelah Timur berbatasan dengan Kecamatan Baki dan sebelah Barat berbatasan dengan Kecamatan Sawit Kabupaten Boyolali. Kecamatan Gatak terdiri dari 14 desa yaitu: Sanggung, Kagokan, Blimbing, Krajan, Geneng, Jati, Trosemi, Luwang, Klaseman, Tempel, Sraten, Wironangan, Trangsan, Mayang. Jumlah penduduk Kecamaan Gatak pada tahun 2019 sebanyak 53.150 jiwa yang terdiri dari 26.572 jiwa penduduk berjenis kelamin laki-laki dan 26.578 jiwa berjenis kelamin perempuan. Kecamatan Gatak memiliki sarana pendidikan yaitu 24 Taman Kanak-kanak, 36 SD/MI, 4 SMP, 1 SMA dan 1 SMK. Penduduk Kecamatan Gatak rata-rata berpendidikan SD/MI sebanyak 5.145 jiwa, SLTP sebanyak 9.425 jiwa, SLTA 13.414 jiwa, D I/II sebanyak 304 jiwa dan S1 sebanyak 2.289 jiwa. Pekerjaan mayoritas dari orang tua di Kecamatan Gatak adalah sebagai buruh pabrik dan tukang batu. Kesibukan ibu yang bekerja sebagai buruh pabrik dan ayah yang bekerja sebagai tukang batu, menyebabkan intensitas komunikasi anak dengan orang tua menjadi berkurang, sehingga pengawasan dan pendampingan orang tua kepada anak ketika bermain gadget menjadi kurang optimal.

Karakteristik orang tua dari siswa BA ini adalah 90\% berpendidikan SLTA dan SLTP, dan sisanya sarjana dan SD. Dari jenis pekerjaannya, mayoritas orang tua/wali merupakan pegawai swasta yaitu karyawan pabrik dan buruh, sementara sebagian kecil sebagai pegawai dan wirasawasta. Dari tingkat ekonominya, rata-rata ekonomi keluarga dari siswa BA berada pada tingkat menengah ke bawah. Menurut informasi 
dari guru, orang tua/wali siswa memiliki kemauan yang besar untuk terlibat dalam kegiatan yang dilakukan oleh pihak sekolah dan orang tua senang jika diberi informasi mengenai perkembangan anak mereka di sekolah.

Salah satu tantangan orang tua di jaman modern ini adalah, besarnya eksistensi teknologi dalam kehidupan anak, sehingga hampir tidak dapat dipisahkan dari aktivitas hidup seharihari, dan salah satunya adalah gadget sebagai bentuk modernitas. Gadget adalah sebuah istilah yang berasal dari bahasa Inggris, yang artinya perangkat elektronik kecil yang memiliki fungsi khusus. Salah satu hal yang membedakan gadget dengan perangkat elektronik lainnya adalah unsur "kebaruan". Artinya, dari hari ke hari gadget selalu muncul dengan menyajikan teknologi terbaru yang membuat hidup manusia menjadi lebih praktis. Gadget adalah salah satu perangkat teknologi yang multifungsi dan perkembangannya sangat cepat. Pengguna gadget bukan hanya kalangan dewasa, bahkan saat ini anak-anak pun sudah sangat mengenal gadget .Anak-anak prasekolah saat ini disebut generasi alpha yaitu generasi yang lahir setelah tahun 2010. Anak-anak generasi alpha ditandai dengan karakteristik lebih terdidik karena peluang mendapatkan pengetahuan yang lebih besar, akrab dan sangat tergantung dengan teknologi, memiliki jarak terjauh dari generasi sebelumnya.Orang tua yang memiliki anak generasi alpha memiliki tantangan dalam cara mengasuh dan mengelola anak-anak mereka. Peran teknologi bagi kehidupan memang luar biasa besar, namun di sisi lain, keberadaan teknologi juga membawa dampak negatif yang tidak sedikit. Hasil penelitian Elfiadi (2018) menjelaskan bahwa pengenalan gadget pada anak sejak usia dini dapat memberikan dampak dan pengaruh, baik positif maupun negatif pada fisik maupun mental anak.Santrock (2012) menjelaskan bahwa gadget mampu memberikan dampak positif bagi anak melalui penayangan berbagai program pendidikan yang dapat mendidik serta memotivasi anak, akan tetapi gadget juga memiliki dampak negatif lain seperti membuat anak menjadi pelajar yang pasif, mengajarkan stereotip, melalaikan pekerjaan rumah, menyediakan model-model yang agresif serta memberikan tayangan yang tidak realistis mengenai dunia. Dampak positif lain dari penggunaan gadget dapat dilihat dari hasil penelitian Herodotou (2018) yang menemukan bahwa penggunaan gadget pada anak berusia 2-5 tahun mampu memberikan dampak positif berupa meningkatnya perkembangan literasi, sains, problem solving dan self efficacy anak. Penggunaan gadget juga akan menimbulkan efek negatif. Melalui gadget anak-anak dapat mengakses konten-konten yang menayangkan kekerasan, kriminal, horor atau film-film yang bersifat maya bukan nyata, oleh karena itu pendampingan aktif dari orang tua sangat diperlukan karena anak belum mampu membedakan antara kehidupan realitas dengan imajinasi cerita yang mereka dapatkan (Mulyadi, 2011). Dampak negatif lainnya dari penggunaan gadget berdasarkan penelitian yang dilakukan oleh Setianingsih, Ardani, dan Khayati (2018), adalah adanya hubungan antara penggunaan gadget dengan risiko gangguan pemusatan perhatian dan hiperkativitas pada anak usia prasekolah.

Dampak negatif dari penggunaan teknologi atau gadget pada anak ini dapat diminimalisir, apabila orang tua dapat berperan optimal dalam pengasuhan. Orang tua perlu memahami karakteristik anaknya, dan memberikan pendampingan di saat anak-anak menggunakan gadget. Hal yang masih banyak ditemui adalah orang tua memberikan fasilitas gadget kepada anak, namun kurang paham mengenai gadget yang digunakan anaknya tersebut. Orang tua kurang memahami fasilitas-fasilitas apa yang ada di dalamnya, fitur-fitur apa yang bisa diakses oleh anak, bagaimana menghindarkan anak dari tayangan kekerasan dan pornografi yang ada di gadget, bahaya atau risiko apa yang mungkin bisa terjadi pada anak jika penggunaanya tidak dibatasi. Hal lain adalah sebagian orang tua justru menjadikan gadget sebagai cara untuk mengalihkan perhatian anak di saat orang tua sibuk, ataupun orang tua yang tidak konsisten dalam mengatur penggunaan gadget oleh anak. Hal ini diperkuat dengan hasil penelitian mengenai alasan yang melatarbelakangi orang tua dalam mengenalkan gadget kepada anak, antara lain: 1) orang tua menganggap gadget sebagai sarana pengenalan teknologi informasi dan komunikasi; 2) gadget sebagai media edukasi untuk menambah wawasan anak; dan 3) gadget sebagai sarana hiburan agar anak 
tidak cerewet dan rewel (Zaini dan Soenarto 2019)

Berdasarkan konsep Psikologi Pendidikan, anak usia prasekolah, secara formal telah memiliki hak untuk belajar di Taman Kanakkanak. Pendidikan Taman Kanak-kanak merupakan pendidikan formal yang diberikan kepada anak dengan usia 4-6 tahun. Sesuai dengan Undang-Undang RI Nomor 20 Tahun 2003 tentang Sistem Pendidikan Nasional, Pasal 28 Ayat (3) menyebutkan bahwa Taman Kanak-kanak adalah suatu bentuk pendidikan yang diselenggarakan untuk mengembangkan kepribadian dan potensi diri sesuai dengan tahap perkembangan peserta didik (Departemen Pendidikan Nasional, 2003).

Dari sisi perkembangan kognitif anak TK, Piaget (dalam Santrock, 2012) menjelaskan bahwa masa anak-anak dengan pendidikan TK telah memasuki tahap praoperasional di mana anak-anak mulai merepresentasikan dunia dengan menggunakan kata-kata, bayangan, dan gambar. Pada tahap inilah perkembangan kepribadian anak dibentuk dan berkembang secara pesat, orang tua seyogyanya bersedia untuk belajar memahami perkembangan kepribadian pada anak, hal tersebut berguna untuk mendeteksi lebih dini apakah anak mengalami masalah dalam perkembangannya. Menurut Novindra, Kurniah, dan Yulidesni (2017) menjelaskan bahwa masalah kepribadian anak akan berdampak pada munculnya masalah-maslah lain pada anak seperti: (1) agresivitas; (2) kecemasan; (3) ketakutan; (4) pemalu, (5) tidak terbuka/toleran. Usia anak di bawah 5 tahun juga merupakan masa emas perkembangan anak, karena pada masa ini aspek fisik, kognitif, bahasa, dan sosial berkembang pesat. Para ahli juga menyebutkan bahwa 90\% perkembangan otak anak terjadi pada fase 5 tahun kehidupannya. Untuk mendukung perkembangan otak anak secara optimal, maka asupan gizi menjadi penting dan orang tua perlu memiliki pemahaman yang baik mengenai hal ini. Salah satu cara untuk mencapainya adalah dengan dilakukan edukasi kepada orang tua untuk meningkatkan pengetahuan mengenai zat gizi yang perlu dikonsumsi oleh anak (Ichsan, Wibowo,\& Sidiq, 2015). Selain pada aspek fisik, peran orang tua pada masa modern ini menjadi sangat penting, karena sejak lahir anak telah terpapar oleh kecanggihan teknologi.

Hasil penelitian Sari \& Mitsalia (2016) menjelaskan bahwa rata-rata anak menggunakan gadget yang mereka miliki untuk bermain game dan menonton kartun daripada untuk keperluan lainnya. Selain itu hasil penelitian Pebriana (2017) menemukan bahwa anak lebih menggunakan gadget untuk bermain daripada belajar, kebiasaan tersebut menyebabkan peran teman sebaya dalam bermain tergantikan oleh gadget, sehingga interaksi sosial anak menjadi terganggu. Personal computer (PC), tablet atau smartphone tidak hanya berisi aplikasi tentang pembelajaran mengenal huruf atau gambar, tetapi terdapat aplikasi hiburan, seperti video, sosial media, gambar, bahkan video game. Anakanak akan lebih sering menggunakan gadget nya untuk bermain game daripada untuk belajar ataupun bermain di luar rumah dengan temanteman seusianya.

Berdasarkan studi literatur yang dilakukan oleh pelaksana, terdapat beberapa teknik intervensi yang telah terbukti berhasil untuk mengurangi kecanduan gadget pada anak. Teknik parent-child game merupakan teknik bermain yang melibatkan anak dan orang tua terbukti dapat menurunkan kecanduan gadget pada anak usia 8-10 tahun (Ramanda, 2018). Alternatif solusi lainnya untuk mengatasi dampak negatif dari gadget, salah satunya adalah peran orang tua. Pemahaman yang benar mengenai perkembangan psikologis anak, serta dampak penggunaan gadget, akan membantu orang tua dalam mengambil sikap yang tepat dalam pengasuhan. Salah satu teknik yang dapat meningkatkan pemahaman kognitif adalah melalui penyuluhan. Beberapa bukti keberhasilan penyuluhan dalam meningkatkan pemahaman antara lain dari penelitian berikut. Penelitian Imanda (2018), membuktikan bahwa penyuluhan dan mind mapping memiliki pengaruh terhadap peningkatan kontrol sosial orang tua dalam penggunaan gadget anak. Selain itu, pelatihan kontrol diri juga dapat menurunkan kecenderungan gangguan terkait penggunaan internet untuk bermain game pada anak usia sekolah (Ramadhani, Iswinarti, \& Zulfiana;2019). Penyuluhan juga dapat meningkatkan pemahaman mengenai 
penggunaan internet sehat. Berdasarkan referensi di atas, dapat disimpulkan bahwa penyuluhan cukup efektif untuk meningkatkan pemahaman. Dengan demikian, pelaksana berencana melakukan pengabdian masyarakat dengan memberikan penyuluhan mengenai cara bijak mendampingi anak dalam menggunakan gadget. Pelaksana melakukan kegiatan pengabdian ini kepada para orang tua/wali dari siswa BA Aisyiyah Trangsan 01. Alasan diadakannya kegiatan ini adalah karena saat ini siswa-siswa BA Aisyiyah Trangsan 01 sudah mulai mengakses gadget sebagai bagian dari aktivitas mereka sehari-hari sehingga dapat menjadi peluang sekaligus ancaman dalam tumbuh kembang anak. Selain itu, orang tua/wali siswa memiliki kemauan untuk mendapatkan informasi-informasi baru mengenai tumbuh kembang anak. Tujuan dari kegiatan pengabdian ini adalah untuk meningkatkan pemahaman orang tua mengenai dampak positif dan negatif dari penggunaan gadget terhadap perkembangan anak, serta dapat bersikap bijaksana dalam mendampingi anak menggunakan gadget .

\section{METODE}

Metode penelitian yang digunakan adalah mixed methods atau metode penelitian perpaduan antara kuantitatif dan kualitatif. Analisis data yang digunakan adalah Wilcoxon Signed Rank Test dan deskriptif kualitatif. Penerima manfaat dari kegiatan ini adalah orang tua/wali siswa BA Aisyiyah Trangsan 01 Gatak Sukoharjo, semua guru, serta pengelola Aisyiyah Ranting Trangsan, yang berjumlah 36 orang.
Langkah-langkah pelaksanaan kegiatan meliputi 3 tahap yaitu tahap persiapan, tahap pelaksanaan, dan tahap akhir, sebagaimana terlihat dalam diagram alir pada gambar 1 .

Sebagaimana tampak pada diagram tersebut, kegiatan dimulai dari tahap persiapan. Tahap persiapan diawali dengan orientasi kancah oleh tim, dengan melakukan survei lapangan dan mencari data awal melalui wawacara kepada pengelola, mempelajari data dokumen, serta melakukan observasi awal di lokasi tempat pengabdian. Tahap ini sekaligus menjadi tahap asesmen kebutuhan (need assessment). Dari orientasi kancah ini diperoleh data awal dan dilakukan analisis kebutuhan., serta dirumuskan kebutuhan mendesak yang perlu segera ditindaklanjuti. Dari hasil analisis kebutuhan diketahui bahwa kebutuhan yang harus segera dipenuhi adalah meningkatkan pengetahuan orang tua dalam mendampingi anak menggunakan gadget. Kebutuhan ini akan ditindaklanjuti dengan kegiatan penyuluhan. Setelah ditetapkan bentuk kegiatannya, maka pelaksana melakukan review literatur untuk bisa mendapatkan materi-materi yang tepat untuk melakukan penyuluhan.

Tahap kedua adalah pelaksanaan. Pengabdian ini dilaksanakan di BA Aisyiyah Trangsan 01 Gatak Sukoharjo, terhadap para orang tua/wali siswa dan seluruh jajaran guru dan staf. Kegiatan dilaksanakan pada hari Rabu, 22 Januari 2020. Kegiatan pengabdian diikuti oleh 36 peserta. Kegiatan pengabdian berupa penyuluhan, meliputi: Pembukaan dan perkenalan, pemaparan materi, diskusi dan tanya jawab, membangun komitmen, dan penutupan.

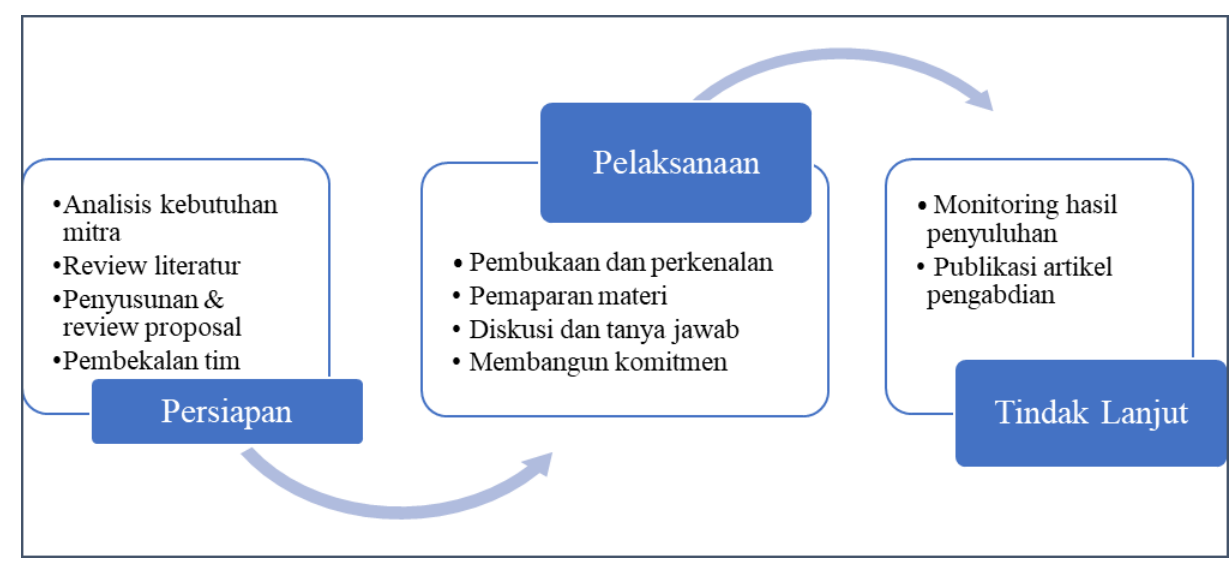

Gambar 1. Diagram Alir Kegiatan Pengabdian 
Media yang digunakan dalam penyuluhan tersebut adalah tayangan power point yang berisi materi tentang karakteristik anak usia TK, dampak positif dan negatif penggunaan gadget dalam perkembangan anak, serta bagaimana peran orang tua dalam menangani dampak negatif penggunaan gadget pada anak. Untuk mengetahui efektifivitas pemberian penyuluhan, akan dilakukan pengukuran dengan memberikan skala kepada orang tua/wali sebelum dan sesudah dilakukan penyuluhan. Apabila tejadi peningkatan skor setelah penyuluhan, maka dapat dimaknakan bahwa peserta penyuluhan memiliki pemahaman yang lebih baik mengenai dampak penggunaan gadget bagi anak dan cara mendampingi anak secara bijak.

Apabila terjadi peningkatan skor setelah penyuluhan, maka dapat dimaknakan bahwa peserta penyuluhan memiliki pemahaman yang lebih baik mengenai dampak penggunaan gadget bagi anak dan cara mendampingi anak secara bijak saat menggunakan gadget. Tahap terakhir adalah tindak lanjut, yang meliputi monitoring hasil penyuluhan. Monitoring dilakukan oleh pelaksana terhadap para guru yang ada di BA Aisyiyah dengan cara melakukan wawancara. Pihak guru selama ini telah menjalin komunikasi dengan orang tua secara rutin untuk memantau kemajuan anak didiknya, sehingga data dari guru cukup untuk bahan tindak lanjut.

\section{Karakteristik responden}

Berdasarkan pada data yang diambil dari identitas orang tua/wali siswa BA Aisyiyah Trangsan 01 didapatkan dua karakteristik dari responden yakni mengenai pekerjaan dan

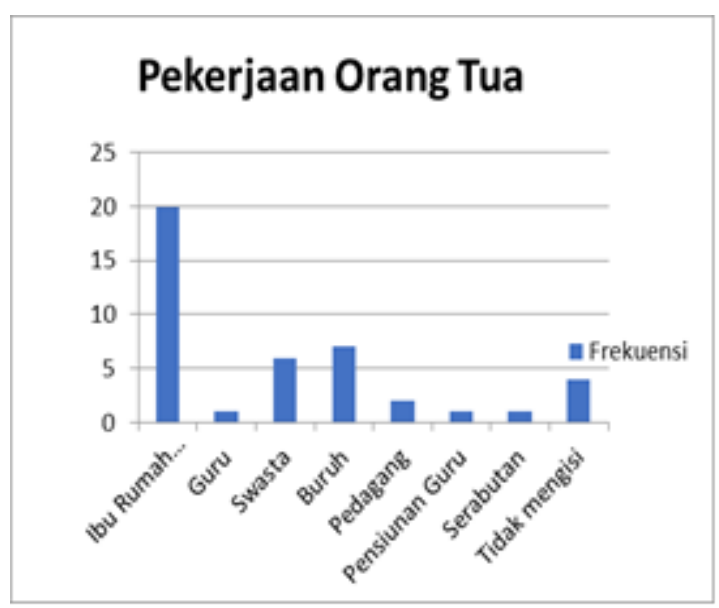

Gambar 2. Karakteristik pekerjaan orang tua pendidikan terakhir. Hasilnya dapat dilihat pada Gambar 2 dan Gambar 3.

\section{HASIL DAN PEMBAHASAN}

Berdasarkan hasil analisis kuantitatif non parametrik dengan Wilcoxon Signed Rank Test didapatkan skor $\mathrm{Z}=-3,134$, dengan $\mathrm{p}=0,002$ $(p<0,05)$. Hal ini menunjukkan bahwa terdapat perbedaan yang sangat signifikan antara skor pretest dan posttest. Hal ini berarti penyuluhan bijak mendampingi anak menggunakan gadget, efektif untuk meningkatkan pengetahuan peserta. Pada bagian positif ranks memiliki nilai 23 yang menunjukkan bahwa 23 orang tua/wali murid dari 36 orang tua/wali murid mengalami peningkatan terhadap pengetahuan dalam pendampingan saat penggunaan gadget. Namun, pada bagian negative ranks memiliki nilai 5 yang menunjukkan bahwa terdapat 5 orang tua/wali murid yang sesudah diberikan perlakuan (pemaparan materi dan tanya jawab) mengalami penurunan pengetahuan terhadap pendampingan anak dalam penggunaan gadget. Pada bagian ties terdapat nilai 8 yang menunjukkan bahwa nilai pretest dan posttest sama. Pada bagian mean di tabel descriptive statistic menunjukkan mean posttest 13,31 yang lebih tinggi dari pada mean pretest 12,06 hal ini menunjukkan bahwa pemaparan materi dan tanya jawab mengenai bijak mendampingi anak prasekolah menggunakan gadget dinilai efektif bagi orang tua/wali murid.

Hasil analisis ini menunjukkan bahwa teknik penyuluhan dapat menjadi alternatif dalam merubah atau meningkatkan pemahaman

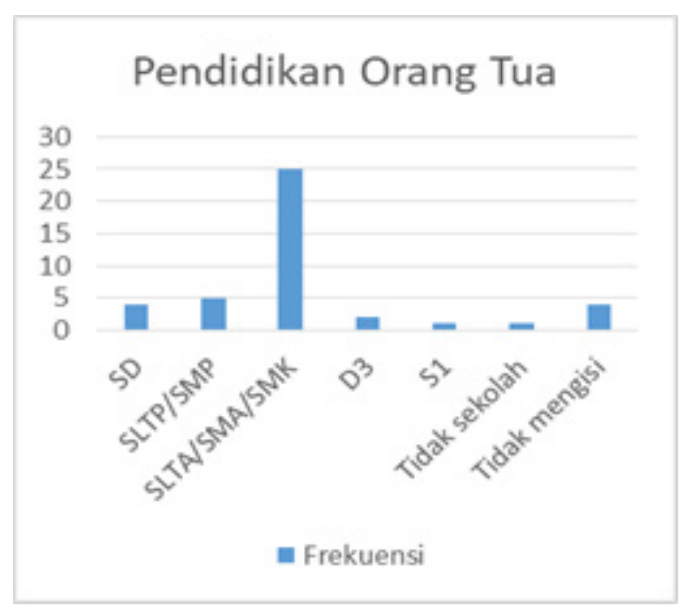

Gambar 3. Karakteristik pendidikan orang tua 
orang tua/wali murid mengenai penggunaan gadget pada anak. Hal ini sejalan dengan penelitian Imanda (2018), yang membuktikan bahwa penyuluhan dan mind mapping memiliki pengaruh terhadap peningkatan kontrol sosial orang tua dalam penggunaan gadget anak. Selain itu, pelatihan kontrol diri juga dapat menurunkan kecenderungan gangguan terkait penggunaan internet untuk bermain game pada anak usia sekolah (Ramadhani, Iswinarti, \& Zuliana, 2019). Penyuluhan juga dapat meningkatkan pemahaman mengenai penggunaan internet sehat.

Peningkatan skor pada peserta penyuluhan merupakan indikasi yang baik karena bekal pemahamaninisangatpentinguntukmendukung orang tua dalam berperan mendampingi anak menggunakan gadget. Dua sisi mata uang pada gadget , menyebabkan orang tua perlu waspada terhadap sisi negatifnya. Hal ini sebagaimana hasil penelitian Pebriana (2017), juga menemukan bahwa anak lebih tertarik menggunakan gadget untuk bermain daripada belajar, kebiasaan itu membuat interaksi anak dengan teman sebaya dalam bermain diambil alih oleh gadget sehingga keterampilan sosial anak menjadi terganggu. Di dalam gadget atau smartphone tersedia fasilitas lengkap yang dapat memenuhi kebutuhan anak akan hiburan/rekreasi, misalnya berupa game, media sosial, video, dan lain-lain, maupun materi belajar, seperti mengenal huruf, angka, atau berbagai objek/gambar. Hal ini tentu saja sangat menarik bagi anak-anak sehingga anakanak menjadi lebih sering menggunakan gadget dibandingkan untuk belajar atau bermain di luar rumah dengan teman-teman sebayanya (Delima, Arianti, \& Pramudyawardani, 2015). Keberadaan orang tua untuk memediasi anak saat bermain gadget menjadi penting, agar anak dapat mengoptimalkan sisi positif dan mendapatkan manfaat dari gadget yang ia gunakan.

Dari sisi perkembangan kognitif anak TK, Piaget (dalam Santrock, 2012) menjelaskan bahwa masa anak-anak dengan pendidikan TK telah memasuki tahap praoperasional di mana anak-anak mulai merepresentasikan dunia dengan menggunakan kata-kata, bayangan dan gambar. Pada tahap inilah perkembangan kepribadian anak dibentuk dan berkembang secara pesat, orang tua seyogyanya bersedia untuk belajar memahami perkembangan kepribadian pada anak, hal tersebut berguna untuk mendeteksi lebih dini apakah anak mengalami masalah dalam perkembangannya. Novrinda, Nina, \& Yulidesni (2017) menjelaskan bahwa masalah kepribadian anak akan berdampak pada munculnya masalah-masalah lain pada anak seperti: (1) agresivitas; (2) kecemasan; (3) ketakutan; (4) pemalu; dan (5) tidak terbuka/toleran. Pendampingan dari orang tua menjadi penting agar anak tidak terjebak pada penggunaan gadget yang merugikan, misalnya dengan bermain game yang mengandung kekerasan atau agresivitas.

Dari data kualitatif yang didapatkan, dapat diketahui bahwa orang tua telah memahami bahwa gadget memiliki dua sisi yakni positif dan negatif (data terlampir). Dampak positif gadget bisa menjadi fasilitator dalam belajar serta dapat mengembangkan kecerdasan anak. Adapun dampak negatifnya yakni anak menjadi lupa waktu, serta tidak dapat fokus terhadap lingkungan sekitarnya. Hal ini sesuai dengan hasil penelitian Elfiadi (2018) yang menyatakan bahwa gadget memiliki dampak yang positif dan negatif. Selain itu Mulyadi (2011) juga mengungkapkan bahwa perlunya pendampingan aktif dari orang tua ketika anak menggunakan gadget, hal ini juga menjadi keinginan para orang tua untuk melakukan pendampingan dengan cara membatasi waktu bermain gadget, mendampingi saat menggunakan, serta pemberian gadget pada usia tertentu saat sudah dirasa mampu mengontrol dirinya sendiri. Menurut hasil penelitian Zain \& Soenarto (2019) alasan orang tua memberikan gadget diantaranya adalah agar anak tidak rewel ketika orang tua sibuk, hal ini juga diungkapkan oleh orang tua/wali murid bahwa orang tua memberikan gadget agar anak tidak rewel saat orang tua sedang melakukan pekerjaan rumah, meskipun demikian orang tua/wali murid juga mengungkapkan bahwa akibat gadget anak menjadi malas belajar.

Materi pelatihan (terlampir) dalam bentuk power point mengenai bijak dampingi anak dalam menggunakan gadget, membantu orang tua untuk dapat bersikap secara tepat dalam menghadapi anak yang menggunakan gadget. Diskusi yang dilakukan saat pelatihan, membuat orang tua dapat berbagi pengalaman dengan 


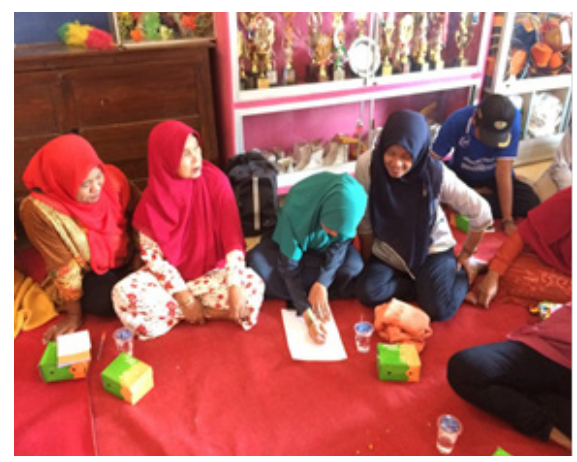

Gambar 4. Pengisian kuesioner

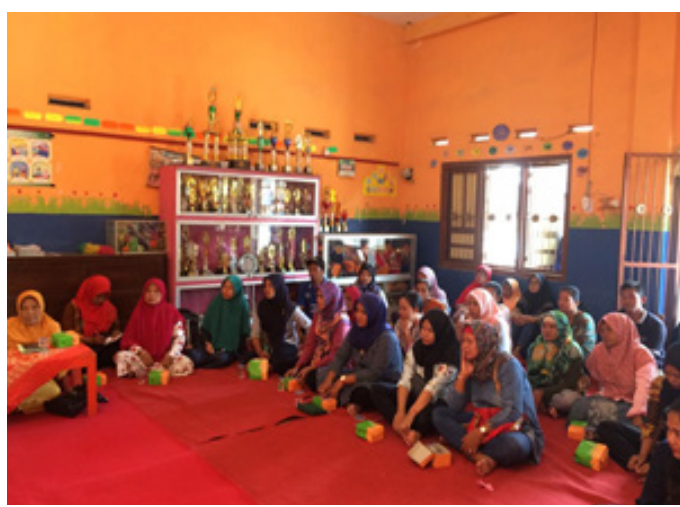

Gambar 6. Peserta menyimak

narasumber maupun orang tua lainnya dalam mengelola anak bermain gadget. Orang tua memahami bahwa anak perlu diberi batasan waktu, pilihan tayangan ataupun konten yang sesuai dengan usianya dan bermanfaat untuk belajar, mendampingi saat anak menggunakan gadget, dan tidak menjadikan gadget sebagai pengasuh pengganti. Orang tuajugaberkomitmen untuk meluangkan waktu lebih banyak dalam beraktivitas bersama anak sehingga ikatan batin antara orang tua dan anak menjadi lebih kuat, dan keinginan anak untuk menggunakan gadget menjadi berkurang.

\section{KESIMPULAN}

Dari paparan di atas dapat disimpulkan bahwa teknik penyuluhan yang digunakan dalam pelaksanaan pengabdian ini dapat membantu orang tua untuk dapat lebih paham dan menjadi bekal untuk dapat bersikap secara tepat saat berhadapan dengan anak yang sedang menggunakan gadget. Selain itu sesi diskusi dan tanya jawab membuat orang tua dapat berbagi pengalaman secara langsung dengan narasumber atau orang tua lainnya. Hasil data kualitatif menunjukkan bahwa orang tua

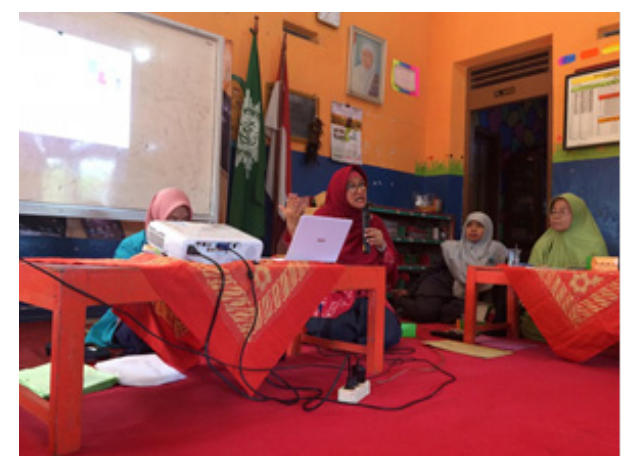

Gambar 5. Pemaparan materi

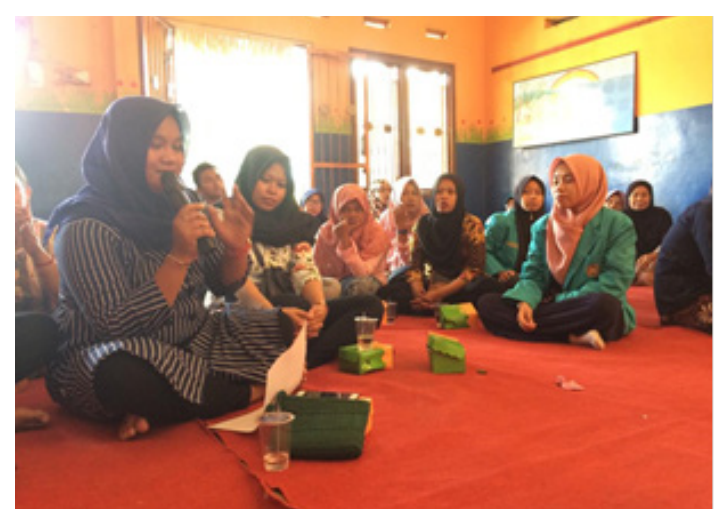

Gambar 7. Diskusi dan tanya jawab

paham akan dampak positif ataupun dampak negatif gadget hal ini membuat orang tua lebih memahami lagi bahwa anak perlu didampingi saat menggunakan gadget agar orang tua juga turut dalam menentukan jenis tontonan anak, memberibatasan waktu, tidakmenjadikangadget sebagai pengganti pengasuh, dan penggunaan gadget untuk sebatas fasilitas belajar anak agar lebih mudah. Pada pengabdian ini orang tua juga berkomitmen untuk meluangkan waktu lebih banyak dalam beraktivitas bersama anak sehingga ikatan batin antara orang tua dan anak menjadi lebih kuat, dan keinginan anak untuk menggunakan gadget menjadi berkurang.

Saran yang dapat diberikan dari kegiatan ini antara lain, penyuluhan ini dapat secara signifikan meningkatkan pemahaman orang tua mengenai perannya dalam mendampingi anak menggunakan gadget. Pemahaman ini hendaknya diikuti dengan aplikasi dalam praktik pengasuhan anak sehari-hari. Orang tua mulai lebih banyak terlibat dalam aktivitas anak, menjadi mediator dalam eksplorasi lingkungan, serta tidak lagi menggunakan gadget sebagai cara untuk merebut hati anak. Dengan mengimplementasikan pemahaman ini, 
maka kehadiran orang tua akan benar-benar dirasakan oleh anak, dan ketergantungan anak terhadap gadget lambat laun akan berkurang. Untuk memantau tingkat implementasi ini, pihak BA Aisyiyah Trangsan 01 dapat secara berkala melakukan home visit dan memfasilitasi orang tua jika mengalami kesulitan dalam pengasuhan. Pengelola BA Aisyiyah juga dapat melakukan penyuluhan untuk materi lainnya sesuai dengan kebutuhan para orang tua dalam mendampingi tumbuh kembang putra putrinya.

\section{PERSANTUNAN}

Ucapan terima kasih penulis sampaikan kepada Fakultas Psikologi UMS yang telah memberi kesempatan untuk melakukan pengabdian masyarakat, kepada Universitas Muhammadiyah Surakarta selaku pihak yang telah memberikan suntikan dana demi terlaksananya pengabdian masyarakat ini, serta kepada guru, staf, dan orang tua/wali siswa BA Aisyiyah Trangsan 01 Gatak Sukoharjo.

\section{REFERENSI}

Delima, Rosa, Nevi Kurnia Arianti, dan Bramasti Pramudyawardani. 2015. Identifikasi Kebutuhan Pengguna untuk Aplikasi Permainan Edukasi bagi Anak Usia 4 sampai 6 Tahun." Jurnal Teknik Informatika dan Sistem Informasi 1(April):2443-2229.

Elfiadi. 2018. Dampak Gadget terhadap Perkembangan. Itqan 9(2):97-110.

Herodotou, C. 2018. "Effects on Learning and Development Open Research Online.

Ichsan, B., Wibowo, B. H., \& Sidiq, M. N. (2015). Penyuluhan Pentignya Sayuran bagi Anak-Anak di TK Aisyiyah Kwadung, Trowangsan, Malangjiwan, Colomadu, Karanganyar, Jawa Tengah. Jurnal Warta,18(1) 29-35.

Imanda, Aulia Nur. 2018. "Pengaruh Intervensi Psikoedukasi Interaktif."

Mulyadi, S. (2011). Psikologi Perkembangan Anak Tiga Tahun Pertama. Bandung: Refika Aditama.

Novindra, Nina Kurniah, and Yulidesni. 2017. "Peran Orang Tua dalam Pendidikan Anak Usia Dini." Raudhatul Athfal: Jurnal Pendidikan Islam Anak Usia Dini 1(1):61-80.

Pebriana, Putri Hana. 2017. "Analisis Penggunaan Gadget Terhadap Kemampuan Interaksi Sosial pada Anak Usia Dini." Jurnal Obsesi : Jurnal Pendidikan Anak Usia Dini 1(1):1.

Ramadhani, Ria Fatma, Iswinarti Iswinarti, dan Uun Zulfiana. 2019. "Pelatihan Kontrol Diri untuk Mengurangi Kecenderungan Internet Gaming Disorder pada Anak Usia Sekolah." Jurnal Ilmiah Psikologi Terapan 7(1):81.

Ramanda, Azalia Putri. 2018. "Parent-Child Games untuk Mengurangi Smartphone Addiction Pada Anak Usia 8-10 Tahun." 1-58.

Santrock, J. W. (2012). Life span development jilid 1. Jakarta: Erlangga.

Sari, Tria Puspita dan Amy Asma Mitsalia. 2016. "Pengaruh Penggunaan Gadget terhadap Personal Sosial Anak Usia Pra Sekolah di Tkit Al Mukmin." Profesi 13(Maret):72-78.

Setianingsih, S., Amila Wahyuni Ardani, dan Fitriana Noor Khayati. 2018. "Dampak Penggunaan Gadget pada Anak Usia Prasekolah dapat Meningkatan Risiko Gangguan Pemusatan Perhatian dan Hiperaktivitas." Gaster 16(2):191.

Zaini, Muhammad dan Soenarto Soenarto. 2019. “Persepsi Orang Tua terhadap Hadirnya Era Teknologi Digital di Kalangan Anak Usia Dini.” Jurnal Obsesi : Jurnal Pendidikan Anak Usia Dini 3(1):254. 